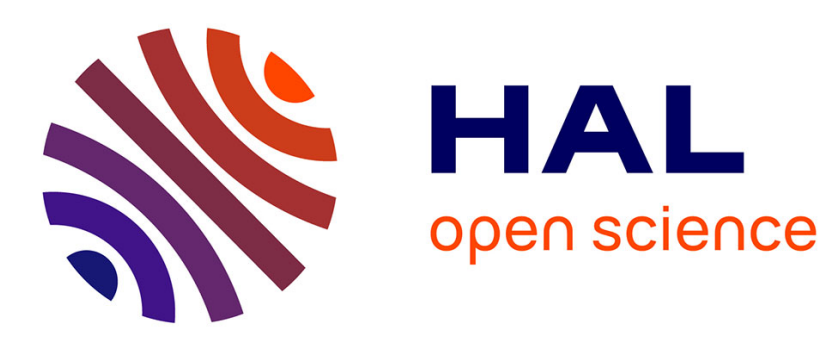

\title{
New specimens of Propotamochoerus (Suidae, Mammalia) from the late Miocene of the Balkans
}

Denis Geraads, Nikolaï Spassov, Risto Garevski

\section{To cite this version:}

Denis Geraads, Nikolaï Spassov, Risto Garevski. New specimens of Propotamochoerus (Suidae, Mammalia) from the late Miocene of the Balkans. Neues Jahrbuch für Geologie und Paläontologie Abhandlungen, 2008, 248 (1), pp.103-113. halshs-00327903

\section{HAL Id: halshs-00327903 \\ https://shs.hal.science/halshs-00327903}

Submitted on 9 Oct 2008

HAL is a multi-disciplinary open access archive for the deposit and dissemination of scientific research documents, whether they are published or not. The documents may come from teaching and research institutions in France or abroad, or from public or private research centers.
L'archive ouverte pluridisciplinaire HAL, est destinée au dépôt et à la diffusion de documents scientifiques de niveau recherche, publiés ou non, émanant des établissements d'enseignement et de recherche français ou étrangers, des laboratoires publics ou privés. 
New specimens of Propotamochoerus (Suidae, Mammalia) from the late Miocene of the Balkans

Denis Geraads, Paris, Nikolaï Spassov, Sofia, and Risto Garevski, Skopje

With 5 figures and 2 tables 
Abstract: We describe new remains of the small Suidae Propotamochoerus from the late Miocene of Macedonia and Bulgaria, which greatly increase the European sample. They are clearly distinct from both the Vallesian P. palaeochoerus and the Pliocene P. provincialis, but cannot be satisfactorily referred to the Asian species $P$. hysudricus or $P$. hyotherioides. It is likely that these Balkan specimens belong to a species of their own, probably distinct from the $P$. palaeochoerus P. provincialis lineage.

Key words: late Miocene, Turolian, Aegean region, Macedonia, Bulgaria, Mammalia, Suidae, Propotamochoerus

\section{Introduction}

During the second part of the late Miocene (Turolian mammal age) of the Eastern Mediterranean, the genus Microstonyx is by far the most common suid. Evolution within this genus is not yet fully agreed upon, but most recent authors recognize only one species, $M$. major, which has been reported from a large number of sites in this area (see e.g., Kostopoulos et al. 2001 for recent studies and review of this taxon).

A few localities of the same period and area (Fig. 1) have yielded a smaller suid, Propotamochoerus, but the previously described material is quite rare (THENIUS 1950, BONIS \& BOUVRAIN 1996). We describe here more remains of this taxon, from three localities in Bulgaria and the Republic of Macedonia.

Bulgaria: The fossiliferous area around Kalimantsi village ( $\mathrm{N} 41^{\circ} 27^{\prime} 30^{\prime \prime}$; E $23^{\circ} 28^{\prime}$ ), in the Middle Struma basin of Bulgaria, includes more than 10 late Miocene mammal localities.

Kalimantsi-1 yielded a fauna which is probably of early Turolian age, including: Proboscidea indet., Deinotherium gigantissimum, Ancylotherium pentelicum, Acerorhinus sp., Hipparion gr. macedonicum, Hipparion cf. brachypus, Bohlinia sp., Helladotherium duvernoyi, Gazella sp., Tragoportax sp., Prostrepsiceros cf. rotundicornis, Mesopithecus sp. (MARKOV 2004, SPASSOV et al. 2006), while other Kalimantsi faunas belong to the middle Turolian, with Hipparion mediterraneum, H. brachypus, Microstonyx major, Helladotherium duvernoyi, Bohlinia attica, Gazella sp., Tragoportax cf. amalthea, Palaeoreas lindermayeri, Adcrocuta eximia and Mesopithecus pentelicus. Detailed comparisons (GERAADS et al. 2003, 2005; KoufOS et al. 2003; Hristova \& Kovachev 2005; SpASSOV et al. 2006, and ref. therein) suggest that these faunas have an age close to that of Pikermi or slightly older, most probably in the first part of the middle Turolian. The precise origin of the scarce Propotamochoerus material described below and stored in the Department of Geology of the University of Sofia (DGUS) is unknown, but as no suid was 
reported from the lowermost level (NIKOLOV, 1985), we may assume that it is probably middle Turolian.

Macedonia: The site of Vozarci near Kavadarsi is a fossiliferous spot (N 41²5'59", E $\left.21^{\circ} 55^{\prime} 17^{\prime \prime}\right)$ which was excavated by one of the authors (R. G.). The material, housed in the Macedonian Museum of Natural History, Skopje, is still undescribed, but a preliminary examination by D.G. and N.S. yields the following list: Hipparion macedonicum, Hipparion proboscideum, Hipparion sp. (group of $H$. schlosseri - H. dietrichi), Hipparion verae (see FORSTÉN \& GAREVSKI 1989), Propotamochoerus sp., Microstonyx sp., Cervidae indet., Helladotherium sp., Bohlinia ? sp., Gazella sp., Prostrepsiceros sp., cf. "Ovis" kuhlmanni, cf. Oioceros sp., Pikermicerus sp., and Tragoportax sp. These taxa suggest again a late early or early middle Turolian age, although BouvRAIN \& BONIS (2007) consider it to be close in age to Dytiko (Axios valley, Greece - MN 13) on the basis of the occurrence of Hispanodorcas (probably our cf. Oioceros) and of a form close to Parastrepsiceros.

Kalnitsa, also near Kavadarsi, yielded a single specimen of Propotamochoerus sp., and a few other taxa: Gazella sp., Palaeoreas sp., Tragoportax sp.

\title{
2. Systematic study
}

\author{
Order Artiodactyla OwEN, 1848 \\ Family Suidae GRAY, 1821 \\ Genus Propotamochoerus PILGRIM, 1925 \\ Propotamochoerus sp.
}

Type-species : Propotamochoerus hysudricus (STEHLIN, 1900)

Vozarci-565 is a right snout fragment of a young adult male, with the root of I3, the canine, and P1-P3, all unworn except for a small wear facet on the mesial edge of the canine (Fig. 2C). There is a small supra-canine flange; above the premolars, the lateral side of the maxilla slopes first dorso-medially, and then becomes vertical, and the snout section was rather square. The size of I3 cannot be estimated from what remains of the root. The canine has just started erupting and is directed antero-ventro-laterally. As far as can be seen, it has three faces, all of them covered by cement but leaving the edges free. The premolars form a continuous series, starting almost immediately behind the canine. P1 is very long and narrow, but low, with a concave lateral side. It consists of two hardly distinct cusps plus a small mesial accessory cusplet. P2 is longer and thicker, higher but still rather low, and consists of one main cusp, plus an anterior cingular cusplet, and a thick disto-lingual cingulum. P3 is intermediate in length between P1 and P2, and about as broad as long. The main tubercle consists of two closely apressed cones, the distal one being also slightly more labial. The disto-lingual cingulum forms an incipient tubercle, giving the tooth a 
trapezoidal outline. The anterior accessory cusplet and associated cingulum are thicker and higher than on $\mathrm{P} 2$.

Vozarci-271 is a female adult palate in medium wear (Fig. 2A). The canine is small, transversely compressed and vertically inserted. The premolar series lacks diastemata, but it starts a short distance behind the canine, perhaps because of the smaller size of this tooth, compared with the male specimen. The morphology and dimensions of the anterior premolars are similar to those of Vozarci-565, except that P3 is narrower, since the main cones are distinctly less thick. P4 has the classic suine morphology, with the paracone well distinct from the metacone, and is longer. The M3 is rather long, with a well-developed talon, in line with the lingual cusps, and no labial cingulum.

Vozarci-895 is a fragment of maxilla with M2-M3 (Fig. 2B). As on Vozarci-271, the talon is not centrally placed, but is in line with the lingual cusps

Vozarci-1632 is another M3, similar to the previous ones.

Vozarci-1544 is a male mandible, lacking only i3 and m3, in medium wear. The incisors are worn only lingually, and i2 is slightly broader than $\mathrm{i}$. The canines are still partly embedded in sediment, but look scrofic. A bi-rooted p1 was present, as shown by its alveoli, separated from $\mathrm{p} 2$ by a diastema $1 \mathrm{~cm}$ long. The latter tooth is long and narrow, but slightly shorter than $\mathrm{p} 3$.

An unnumbered female mandible from Vozarci bears p2-m3 on the right side, plus p1 and a fragment of the canine on the left one (Fig. 2H). Again, p1 is bi-rooted, and separated from 2 by a diastema. The p4 is moderately worn; it is short and broad, with a massive main cuspid, and no distinct Innenhügel; the talonid is quite short; there is a broad dentine contact between it and the main conid, and the labial groove separating them is more distal than the lingual one. The talonid of $\mathrm{m} 3$ consists of one main cuspid (pentaconid of VAN DER MADE, 1996), plus a minute accessory lingual pillar (hexaconid).

Vozarci-564 is a left tooth-row with p3-m3 (Fig. 2F). As on Vozarci-1544, p3 is slightly longer than $\mathrm{p} 4$, which again has a short talonid. On $\mathrm{m} 3$, the pentaconid is labially shifted, and there is a relatively large hexaconid.

Vozarci-563 and Vozarci-1108 are two right m3s. On both teeth, the talonid consists of one main pentaconid in the midline, plus a small hexaconid.

An unnumbered mandible from Kalnitsa bears p2-m3 (Fig. 2G). The p1 is now missing but, behind the canine, a bulge in the mandibular corpus was probably caused by its roots, strongly suggesting that this tooth was present in life. All other premolars are almost of the same length, and were probably rather low in the unworn state. The $\mathrm{p} 2$ is very narrow, but a clear pinching marks the talonid. The other premolars do not differ significantly from the previously mentioned specimens, but weathering prevents detailed description. The surface of $\mathrm{m} 3$ is also weathered, but 
it is clear that the talonid consisted of two tubercles, the lingual one (hexaconid) being only slightly smaller than the main one (pentaconid).

The material from Kalimantsi consists of an isolated P2 and a M3. On P2 (Fig. 2E) the protocone is quite strong, giving the tooth a high $\mathrm{W} / \mathrm{L}$ ratio, but it is too narrow for a $\mathrm{P} 3$. The M3 (Fig. 2D) is slightly narrower anteriorly than the Macedonian specimens, but otherwise similar, with the talon in line with the lingual cusps.

\section{Comparisons}

The suids from Macedonia and Bulgaria can be compared to several taxa from the late Miocene and early Pliocene, which are smaller than Microstonyx, the common European suid of this period, but larger than Sus, and are usually assigned to the genus Propotamochoerus.

Propotamochoerus palaeochoerus (KAUP, 1833) is best known from the Vallesian of Central Europe (MotTL 1966; HÜNERMANN 1968; SCHMIDT-KITTLER 1971) and Ukraine (VAN DER MADE et al. 1999). A record of earlier age is Montréjeau, France (HüNERMANN 1968), but reports from younger localities are doubtful. A suid from Maramena, Serres, N. Greece, was described under this name by HELLMUND (1995), and a maxilla from Salihpaşalar, Turkey, is also labelled as such in the Museum of the General Directorate of Mineral Research and Exploration, Ankara (MTA-2383). The material from Alcoy, Spain, previously assigned to this species has recently been re-assigned to Sus arvernensis (MONTOYA et al. 2006). Propotamochoerus palaeochoerus was also listed from Tataros in Romania by RABEDER (1985); the material is too poor for specific identification but the genus is probably correct.

Propotamochoerus hysudricus (STEHLIN, 1900) from the Indian subcontinent has a complex synonymy list (reviews in PICKFORD 1988; BONIS \& BOUVRAIN 1996), but is unfortunately poorly illustrated (PILGRIM 1926; PICKFORD 1988). A mandible of a similar form has been described by BONIS \& BOUVRAIN (1996) from the early Turolian of Ravin des Zouaves n5 (RZO), and another has been discovered by E. TsOUKALA at Thermopigi, both in Northern Greece.

Propotamochoerus hyotherioides (SCHLOSSER, 1903) is mostly known by isolated teeth from Lufeng, China (VAN DER MADE \& HAN, 1994) but PEARson (1928) also illustrated a palate and a mandible from Loc. 49. This Chinese species was included in Hippopotamodon by PICKFORD \& LIU (2001), and there are indeed a number of similarities between it and both species of this genus, $H$. sivalense from the Middle Siwaliks of Pakistan, and $H$. antiquus from the early Late Miocene of Western Eurasia, which are significantly larger, however. Pending revision of the whole group, we follow common practice in referring hyotherioides to Propotamochoerus. THENIUS (1950) referred to the same species a mandible and associated maxilla from Samos that BONIS \& BOUVRAIN (1996) compared instead to the RZO form. Mitzopoulos (1947) also 
reported a maxilla fragment from Achladi in Euboea, while GALLAI \& ROOK (2006) referred to this species or the preceding one a few specimens from Sicily.

Propotamochoerus provincialis (GERVAIS, 1852) has been reported from several latest Miocene and early Pliocene European sites, but is best known from the early Pliocene of Montpellier; the material has never been published in detail, but we were able to study a good sample in "Université Claude Bernard" and "Centre de Conservation et d' Etude des Collections", Lyon. The species is also present at Malusteni, Romania (SIMIONESCU 1930) but the specimens from Kvabebi, Georgia (VEKUA 1972; VEKUA et al. 2005) are clearly not of this species, as noted by AZZAROLI (1975).

P1: In the Late Miocene, this tooth is bi-rooted, bi-cuspidate, and low, as at Vozarci. On the male specimen of $P$. palaeochoerus described by MotTL (1966), the diastema separating this tooth from P2 is much longer than in all other forms. Specimen FSL-40073 of P. provincialis from Montpellier displays only the root of a monoradiculate vestigial P1, almost contacting both the canine and P2; this tooth was therefore much more reduced than at Vozarci.

P2: In P. palaeochoerus, and in P. hyotherioides from Lufeng, P2 is distinctly narrower anteriorly than posteriorly, and the protocone is better-marked than at Vozarci or at Samos, where the tooth is of more regular width. The tooth from Kalimantsi has a very strong protocone, and is the broadest of all Propotamochoerus P2s, but there is no other taxon to which it could be referred. At Maramena P2 is longer than P3, as at Vozarci, whereas they are about as long in other sites, but in $P$. provincialis, instead, this tooth is smaller than $\mathrm{P} 3$.

P3: The protocone is variable in $P$. palaeochoerus, but in this species as well as in the other ones, it is always larger than at Samos. The main cusp is usually double, except in specimens from the Indian subcontinent assigned to $P$. hysudricus, where the main cusp is stout and rounded, more like at Maramena and in P. provincialis.

P4: This tooth has a rather constant morphology. The paracone is usually slightly larger than the metacone, but the difference in size between these cusps is more important, and the protocone slightly shifted mesially, in the specimen from Gravitelli, in P. hyotherioides from Lufeng, and especially in $P$. provincialis.

M3: The size of the talon (pentacone of VAN DER MADE, 1996) is not very variable, but in $P$. palaeochoerus it is situated centrally, so that the tooth is almost symmetrical. One exception is the specimen from Grytsiv. In younger forms, instead, the pentacone is lingually shifted, and almost in line with the protocone and "hypocone" (tetracone of VAN DER MADE, 1996), and the tooth is no longer symmetrical, but more triangular. This might be connected with the overall trend towards development of the hexaconid on $\mathrm{m} 3$ (see below).

Lower canine: The mandible from Vozarci seems to have canines of scrofa-type, as in all 
other taxa. HÜNERMANN (1968) showed that both the size and detailed morphology are rather variable within $P$. palaeochoerus.

p1: In the Indian P. hysudricus, this tooth is inserted immediately behind the canine. In the Vozarci mandible, it is inserted less than $1 \mathrm{~cm}$ behind it, but a longer diastema separates it from p2. The condition is very similar in the RZO and Samos mandibles, and in P. provincialis, but the diastema between $\mathrm{p} 1$ and $\mathrm{p} 2$ is shorter, if not absent, in $P$. hysudricus from India.

p2: This tooth displays little variation, except that those from RZO are large. A premolar from Tataros, Romania, is definitely too small to be a p3, but is even smaller and broader than those of P. palaeochoerus; it is probably best assigned to this latter taxon.

p3: In the Macedonian specimens, this tooth is broad (Fig. 3) but oval-shaped, and more similar to $\mathrm{p} 2$ than to $\mathrm{p} 4$; the same is true of $\mathrm{p} 3 \mathrm{~s}$ from RZO. In P. palaeochoerus, $\mathrm{p} 3$ is also ovalshaped, but quite narrow. The p3s of the Indian $P$. hysudricus are always short, in contrast to the $P$. cf. hysudricus from RZO.

p4: The p4s of $P$. palaeochoerus (HLMD Din-3, Din-48, Din-94) are quite distinct from those of the Balkans by their strong protruding Innenhügel and by their talonid remaining long isolated from the trigonid. VAN DER MADE \& HAN (1994) illustrated only unworn or little worn p4s of P. hyotherioides from Lufeng, but they look more similar to those of $P$. palaeochoerus than to those of the Balkan form, because the main cuspid is clearly subdivided, and the grooves limiting the talonid more deeply incised. Most of the $\mathrm{p} 4 \mathrm{~s}$ of $P$. provincialis that we have seen are not much worn but, even on the oldest specimen (FSL 40884), the talonid remains well separated from the trigonid, which has a rather strong metaconid. By contrast, on the $\mathrm{p} 4$ of the mandible from Ravin des Zouaves referred to $P$. cf. hysudricus, the dentine island is continuous as at Vozarci, although the tooth is not much worn (BonIS \& BouVRAIN 1996, Fig. 9).

If we compare the length proportions, the pattern is clearer than for p3 (Fig. 4). All specimens assigned to $P$. palaeochoerus (except one aberrant mandible from Hennersdorf: HELLMUND 1995) have long p4s (as noted by VAN DER MADE et al. 1999), whereas the $\mathrm{p} 4 / \mathrm{m} 3$ ratio is smaller and more or less the same in all other forms, including those from Vozarci, RZO and Lufeng, that have long p3s.

The $\mathrm{m} 1 \mathrm{~s}$ and $\mathrm{m} 2 \mathrm{~s}$, often much worn, do not display significant differential features.

m3: An important issue is the significance of the variations in the composition of the distal complex. There is some variation at Vozarci, and it is well-known that Plio-Pleistocene African suids display a great range of variation in this structure, even within a single stratigraphic level. On the other hand, VAN DER MADE et al. insisted (VAN DER MADE et al. 1999: 286) on the occurrence of two pillars in the distal lobe of the RZO specimen, and suggested (VAN DER MADE et al. 1999: 290) that this has taxonomic significance, the hexaconid being absent in $P$. palaeochoerus and 
$P$. hysudricus. However, the sample of $P$. provincialis from Montpellier clearly demonstrates that intra-specific variation may be quite large. In some specimens from this locality (FSL 40155, FSL 40161), the distal complex consists almost only of the pentaconid, with only minor accessory tubercles; others have a stronger hexaconid (FSL 40070, FSL 40072); others (FSL 40175, FSL 40881) have an almost symmetrical distal complex, with the hexaconid even larger than the pentaconid (but no hint of a heptaconid). Thus, the variation at Montpellier is even larger than at Vozarci. It is therefore clear that the occurrence of one or two cuspid in the distal complex of m3 is insufficient to support a taxonomic distinction. What remains true, however, is that there is a clear trend, from the Vallesian to the Ruscinian, for the distal complex to become more often bicuspid.

We performed a principal component analysis on the most significant lower teeth, excluding $\mathrm{p} 1$ and $\mathrm{p} 2$ because they are too rare, and $\mathrm{m} 1-\mathrm{m} 2$ because their measurements are often reduced by wear. Results, shown in Fig. 5, mostly confirm those of the bivariate plots. Propotamochoerus provincialis is distinct by its large size. The variation of the Indian $P$. hysudricus is probably too large to be accommodated within a single species.

Propotamochoerus palaeochoerus from the Vallesian has long and broad p4s, and is well-distinct in this regard from all other forms, including the one from Maramena. The third axis of the PCA (inertia: $7.68 \%$ ) describes mostly the width of the premolars, and separates clearly the Macedonian specimens (but not so clearly the RZO form) from the Lufeng P. hyotherioides.

\section{Discussion and conclusions}

It is likely that all the forms from Kalnitsa and Vozarci (Macedonia), Kalimantsi (Bulgaria), RZO, Samos, Achladi, and Thermopigi (Greece), all belong to the same species, which remains relatively rare and co-exists, at Vozarci, Kalimantsi, RZO, and Thermopigi, with the large Microstonyx. From Salihpaşalar (Turkey), PICKFORD \& ERTÜRK (1979) reported only Microstonyx, but the maxilla mentioned above is similar in size and morphology to Propotamochoerus, and likely belongs to this genus as well, rather than to Hippopotamodon, represented in Turkey by a larger and earlier species. The material from Maramena is probably of the same taxon; it lacks the features of $P$. palaeochoerus, especially the large p4 and symmetrical M3, but in spite of the relatively recent age of the locality, the third molars are smaller than in P. provincialis.

Propotamochoerus palaeochoerus is well-distinct from this Turolian form, and it may even be doubted that they belong to the same genus; thus, "Korynochoerus" palaeochoerus might indeed deserve a distinct generic name. The skull from Johnsdorf described by MOTTL (1966) has very large supra-canine flanges, and the premolars are quite distinct: P1 is small and separated from $\mathrm{P} 2$ by a long diastema, $\mathrm{P} 2$ is also short but much broader distally than mesially, P3 has a very 
large protocone giving the tooth a triangular outline, and P4 is shorter lingually than labially. On the whole, the premolars are significantly more reduced than at Vozarci. Furthermore, in $P$. palaeochoerus, the talon of M3 is centrally placed, instead of being almost in line with the protocone and hypocone. Besides these dental differences, compared with that of $P$. hysudricus, the skull and especially the snout are longer, the supra-canine flange is larger, the zygomatic arches more expanded anteriorly, and the temporal lines meet in the sagittal plane.

Propotamochoerus provincialis has slightly longer M3s and m3s than the Balkan form, P1 and $\mathrm{P} 2$ are reduced, the protocone of $\mathrm{P} 4$ is shifted mesially, $\mathrm{p} 3$ is broad distally, the talonid of $\mathrm{p} 4$ is well-distinct from the main cuspid, and the third lobe of $\mathrm{m} 3$ trends towards bicuspidy.

Interestingly, some features of this species are shared by P. palaeochoerus, but not by the Eastern Mediterranean form, and one could imagine that $P$. provincialis is an independent offshoot from the Vallesian form.

The comparison of the Balkan form with P. hysudricus and $P$. hyotherioides is less straightforward, because:

- both named species are based upon inadequate material and remain poorly defined;

- as we have seen above, and as already noted by BONIS \& BOUVRAIN (1996), the Indian material referred $P$. hysudricus probably includes more than one species;

- cranial material is known only for "P. hysudricus".

Assignment of the Balkan form to either P. hysudricus or $P$. hyotherioides would not be very satisfactory, and it is likely that it belongs in fact to an as yet unnamed species, restricted to the Aegean region, but this remains to be further supported by cranial material. Its age remains at the present time poorly constrained. Ravin des Zouaves has been assigned to "zone" MN 11; the tooth from Kalimantsi is likely from the first half of the middle Turolian, but the faunas of the Republic of Macedonia have not yet been studied in detail, although an MN 11 or early MN 12 age is likely for Vozarci. We may assume, as a working hypothesis, that most Propotamochoerus localities of the Balkans and Turkey, except Maramena, belong to the first half of the Turolian.

The last species of the genus, P. provincialis, became extinct in the Middle Pliocene; it is at that time that a related genus, Kolpochoerus, is first recorded Africa, first by K. deheinzelini BRUNET \& WHITE, 2001, a species which is still poorly known and of uncertain status (GERAADS, 2004), and later, at about 3.5 - 3 Ma., by K. afarensis COOKE, 1978. A close relationship between both genera is generally accepted, and one may conceive that some species of Propotamochoerus gave rise to the African forms, which are more derived by their less straight cranial profile, backward retraction of the zygoma and longer muzzle, larger upper canine, and more complex P3 (with a mesio-lingual cusp which is always absent in Propotamochoerus). However, $P$. provincialis is an unlikely ancestor for Kolpochoerus because of its thick premolars, mesially 
shifted protocone on $\mathrm{P} 4$, and talonid of $\mathrm{m} 3$ more complex than in early Kolpochoerus, so that if the latter arose from a Eurasian immigrant, this must have happened in the latest Miocene, which would confirm K. deheinzelini as a member of this genus.

\section{Acknowledgements}

D. Berthet (Centre de Conservation et d'Etude des Collections, Lyon), G. GRÜBER (Hessisches Landesmuseum, Darmstadt), M. IVANOv (Department of Geology, University of Sofia), and A. PRIEUR (Université Claude Bernard, Lyon), kindly gave us access to collections in their care. V. CODREA and M. GASPARIK provided data about the Tataros suid. Special thanks to L. HRISTOVA for her preliminary identifications of hipparions, to D. NAGEL for helpful comments, and to E. TsOUKALA for showing us her Thermopigi fossils. Remarks and suggestions by M. PICKFORD and an anonymous reviewer greatly improved the manuscript. All travel funds were provided by the CNRS, UPR 2147.

\section{References}

AzZAROLI, A. (1975): Remarks on the Pliocene Suidae of Europe. - Zeitschrift für Säugetierkunde, 40: $355-367$.

Bonis, L. de \& Bouvrain, G. (1996): Suidae du Miocène supérieur de Grèce. - Bulletin du Muséum national d'Histoire naturelle, 18: 107-132.

Bouvrain, G. \& Bonis, L. de (2007): Ruminants (Mammalia, Artiodactyla: Tragulidae, Cervidae, Bovidae) des gisements du Miocène supérieur (Turolien) de Dytiko (Grèce). - Annales de Paléontologie, 93: 121-147.

Brunet, M. \& White, T.D. (2001): Deux nouvelles espèces de Suini (Mammalia, Suidae) du continent africain (Ethiopie; Tchad). - Comptes-Rendus de l'Académie des Sciences, Sciences de la Terre et des Planètes, 332: 51-57.

CoOKE, H.B.S. (1978): Pliocene-Pleistocene Suidae from Hadar, Ethiopia. - Kirtlandia, 29: 1-63. Forsten, A. \& GAREvski, R. (1989): Hipparions (Mammalia, Perissodactyla) from Macedonia, Yugoslavia. - Geologica macedonica, 3: 159-206.

Fortelius, M., Armour-Chelu, M., Bernor, R. L. \& Fessaha, N. (2005): Systematics and Palaeobiology of the Rudabánya Suidae. - Palaeontographia Italica, 90: 259-278.

Gallai, G. \& RooK, L. (2006): Propotamochoerus sp. (Suidae, Mammalia) from the late Miocene of Gravitelli (Messina, Sicily, Italy) rediscovered. - Rivista Italiana di Paleontologia e Stratigrafia, 112: 317-321.

GERAADS, D. (2004): New skulls of Kolpochoerus phacochoeroides (Suidae, Mammalia) from the late Pliocene of Ahl al Oughlam, Morocco. - Palaeontologia africana, 40: 69-83. 
Geraads D., Spassov N. \& Kovachev D. (2003): Palaeoreas lindermayeri (Wagner, 1848) from the upper Miocene of Bulgaria, and a revision of the species. - Géodiversitas, 25(2): 405415.

GeraAds, D., Spassov, N. \& Kovachev D. (2005): Giraffidae (Artiodactyla, Mammalia) from the late Miocene of Kalimantsi and Hadjidimovo, South-Western Bulgaria. Geologica Balcanica, 35 (1-2): 11-18.

Gervais, P. (1848-1852): Zoologie et Paléontologie françaises. - 271 p.; Paris (A. Bertrand).

Hellmund, M. (1995): The Vertebrate Locality Maramena (Macedonia, Greece) at the Boundary Turolian-Ruscinian Boundary (Neogene). 13 Suidae (Artiodactyla, Mammalia). Münchner Geowissenschaftliche Abhandlungen, 28: 143-156.

Hristova, L. \& Kovachev, D. (2005): Notes on the Taxonomy of the Middle Turolian Hipparions from the Localities near Kalimantsi Village. Proceedings of the International Scientific Conference (8-11.06.2005). Faculty of Mathematics and Natural Sciences. South-Western University, Blagoevgrad, 180-184. (in Bulgarian, Engl. summary). HÜnermanN, K. A. (1968): Die Suidae (Mammalia, Artiodactyla) aus den Dinotheriensanden (Unterpliozän= Pont) Rheinhessens (Südwestdeutschland). - Schweizerische Paläontologische Abhandlungen, 86: 1-96.

Kostopoulos, D. S., Spassov, N. \& Kovachev, D. (2001): Contribution to the study of Microstonyx: evidence from Bulgaria and the SE European populations. - Geodiversitas, 23(3): 411-437.

Koufos, G. D., Spassov, N. \& Kovachev, D. (2003): Study of Mesopithecus (Primates, Cercopithecidae) from the late Miocene of Bulgaria. - Palaeontographica A, 269: 39-91. Markov, G. N. (2004). The fossil Proboscideans of Bulgaria. Unpubl. PhD Thesis, Sofia, 225 p. (in Bulgarian with English summary).

Mitzopoulos, M. K. (1947): Die Verbreitung der Pikermistufe auf der Insel Euböa. - Annales géologiques des Pays Helléniques, 1: 209-216.

Montoya, P., Ginsburg, L., Alberdi, M.-T., Van der Made, J., Morales, J. \& Soria, M.-D. (2006): Fossil large mammals from the early Pliocene locality of Alcoy (Spain) and their importance in biostratigraphy. - Geodiversitas 28(1): 137-173.

MotTL, M. (1966): Ein vollständiger Hyotherium palaeochoerus-Schädel aus dem Altpliozän (Pannon) Südost-Österreichs. - Mitteilungen des Museums für Bergbau, Geologie und Technik am Landesmuseum "Joanneum", 28: 73-103.

Nikolov, I. (1985): Catalogue of the localities of tertiary Mammals in Bulgaria. - Paleontology, Stratigraphy and Lithology, 21: 43-62.

Pearson, H. S. (1928): Chinese fossil Suidae. - Palaeontologia Sinica, 5: 1-75. 
PICKFORD, M. (1988): Revision of the Miocene Suidae of the Indian Subcontinent. - Münchner Geowissenschaftliche Abhandlungen, 12: 1-95.

PICKFORD, M. \& ERTÜRK, Ç. (1979): Suidae and Tayassuidae from Turkey. - Bulletin of the Geological Society of Turkey, 22: 141-154.

PICKFORD, M. \& LIU LIPING (2001): Revision of the Miocene Suidae of Xiaolongtan (Kaiyuan), China. - Bolletino delle Società Paleontologica Italiana, 40: 275-283.

Pilgrim, G. E. (1925): Presidential address to the geological section of the 12th Indian Science company. - Proceedings of the 12th Indian Science Congress: 200-218. [not seen; fide PICKFORD, 1988]

Pilgrim, G. E. (1926): The fossil Suidae of India. - Memoirs of the Geological Survey of India. Palaeontologia Indica, 8(4): 1-65.

Rabeder, G. (1985): Die Säugetiere des Pannonien. - In: PAPP, A., JAMBOR, A. \& Steininger, F. (Eds): Chronostratigraphie und Neostratotypen. Miozän der Zentralen Paratethys. M6 Pannonien, 440-463; Budapest (Ungarischer Akademie der Wissenschaften).

Schlosser, M. (1903): Die fossilen Säugetiere Chinas nebst einer Odontographie der rezenten Antilopen. - Abhandlungen der bayerischen Akademie der Wissenschaften, 7: 371-464. SCHMidT-KITTLER, N. (1971): Die obermiozäne Fossillagerstätte Sandelzhausen, 3. Suidae (Artiodactyla, Mammalia). - Mitteilungen der bayerischen Staatssammlung für Paläontologie und historische Geologie, 11: 129-170.

SimionesCU, I. (1930): Vertebratele Pliocene dela Malusteni (Covurlui). - Academia RomanaPublicatiunile Adamachi, 9: 83-148.

Spassov, N., TzANKOV, Tz. \& GERAADS, D. (2006): Late Neogene stratigraphy, biochronology, faunal diversity and environments of South-West Bulgaria (Struma River valley). Géodiversitas, 28(3): 477-498.

Stehlin, H. (1900): Ueber die Geschichte des Suiden-Gebisses. - Mémoires Suisses de Paléontologie, 26: 1-527.

THENIUS, E. (1950): Postpotamochoerus nov. subgen. hyotherioides aus dem Unterpliozän von Samos (Griechenland) und die Herkunft der Potamochoeren. - Sitzungsberichten der Österreichischen Akademie der Wissenschaften Mathematisch-Naturwissenschaftliche Klasse, 159: 25-36.

VAN DER MADE, J. (1996): Listriodontinae (Suidae, Mammalia), their evolution, systematics and distribution in time and space. Contributions to Tertiary and Quaternary geology, 33: 3254.

VAN DER MADE, J. \& HAN, D. (1994): Suoidea from the upper Miocene hominoid locality of Lufeng, Yunnan province, China. - Proceedings of the Koninklijke Nederlandse Akademie 
van Wetenschappen, 97: 27-82.

Van der Made, J., Krakhmalnaya, T. \& Kubiak, H. (1999): The pig Propotamochoerus palaeochoerus from the Upper Miocene of Grytsiv, Ukraine. - Estudios geológicos, 55: 283-292.

VeKUA, A.K. (1972): Kvabebskaia fauna Akchagylskih Pozvonochnyh. - 1-350; Moskva (Nauka) [in Russian].

VeKuA, A., LordKIPANidze, D., Agustí, J. \& OMs, O. (2005): The Pliocene mammal site of Kvabebi (Eastern Georgia): new field campaigns and age determination. Geophysical Research Abstracts, 7: 08450.

\section{CAPTIONS TO FIGURES:}

Figure 1: map of the Eastern Mediterranean, with the late Miocene Propotamochoerus localities.

Figure 2: Propotamochoerus sp. Upper teeth are shown as if from the right side, lower teeth as if from the left side. A: upper right tooth row, Vozarci-271; B: upper left (reversed) M2-M3, Vozarci-895; C: upper right C-P3, Vozarci-565; D: upper right M3 from Kalimantsi; E: upper right P2 from Kalimantsi; F: lower left p3-m3, Vozarci-564; G: lower left p2-m3 from Kalnitsa; H: unnumbered mandible with left c-p1 and right p2-m3 (reversed), from Vozarci. Scale $=10 \mathrm{~cm}$.

Fig. 3: Plot of p4 width vs. p3 width in Propotamochoerus. Mean values are shown by larger symbols.

Fig. 4: Plot of m3 length vs. p4 length in Propotamochoerus. Mean values are shown by larger symbols.

Fig. 5: Plane 1-2 of the PCA on lower teeth measurements, using : well preserved tooth-rows and the mean values of $P$. hysudricus from India (PICKFORD 1988), the mean values of P. palaeochoerus from Wissberg (HÜNERMANN 1968), the mean values of a number of other Vallesian specimens of $P$. palaeochoerus from Central Europe (HÜNERMANN 1968; HELLMUND 1995), the mean values of $P$. palaeochoerus from Maramena (HELLMUND 1995), the mean values of P. palaeochoerus from Rudabánya (FoRTELIUS et al. 2005), two well-preserved specimens of P. palaeochoerus from Grytsiv (VAN DER MADE et al. 1999), the mandible of $P$. cf. hysudricus from Ravin des Zouaves 5 (BONIS \& BOUVRAIN 1996), the mean values of P. hyotherioides from 
Lufeng (VAN DER MADE \& HAN 1994) and the mandibles Vozarci-564 and Kalnitsa. Illustrative individuals are italicized. Mean values are represented by larger symbols.

Addresses of the authors:

Denis GeraADS, UPR 2147 CNRS, 44 rue de l'Amiral Mouchez, 75014 Paris, France, dgeraads@ivry.cnrs.fr (corresponding author)

NikOLAÏ Spassov, National Museum of Natural History, Tsar Osvoboditel Blvd 1, 1000 Sofia, Bulgaria,nspassov@nmnh.bas.bg

Risto GAREVSKI, Macedonian Museum of Natural History, Ilinden Blvd 86, 91000 Skopje, Republic of Macedonia 
Table 1. Measurements of the upper teeth

\begin{tabular}{|l|c|c|c|c|c|c|c|c|c|c|c|c|}
\hline & L P1 & W P1 & L P2 & W P2 & L P3 & W P3 & L P4 & W P4 & L M2 & W M2 & L M3 & W M3 \\
\hline Vozarci-271 & 12.7 & 4.4 & 16.1 & 9 & 14.5 & 13.1 & 13.2 & 16.6 & 22.3 & 21.3 & 29.5 & 21.1 \\
\hline Vozarci-565 & 12.8 & 4.5 & 16.4 & 10 & 14.5 & 14.7 & & & & & & \\
\hline Vozarci-895 & & & & & & & & & 22.8 & 20.1 & 30.7 & 21 \\
\hline Vozarci-1632 & & & & & & & & & & & 33.4 & 23.5 \\
\hline Kalim.DGUS-33 & & & & & & & & & & & 29.5 & 19.5 \\
\hline Kalim.DGUS & & & 16.2 & 11.2 & & & & & & & & \\
\hline
\end{tabular}


Table 2 . Measurements of the lower teeth

\begin{tabular}{|l|c|c|c|c|c|c|c|c|c|c|c|c|}
\hline & L p2 & W p2 & L p3 & W p3 & L p4 & W p4 & L m1 & W m1 & L m2 & W m2 & L m3 & W m3 \\
\hline Kalnitsa & 14.4 & 6.3 & 15.5 & 9.7 & 15.8 & 12.1 & & 12.8 & 21.2 & 16.8 & 32 & 18.1 \\
\hline Vozarci-563 & & & & & & & & & & & 33.8 & 18.8 \\
\hline Vozarci-564 & & & 16.9 & 10.4 & 16.3 & 12.5 & & & & & 34.5 & 18.7 \\
\hline Vozarci-1108 & & & & & & & & & & & 33.4 & 18.2 \\
\hline Vozarci-1544 $^{16.6}$ & 6.8 & 16.8 & 10 & 15.3 & 11.8 & 15 & 12.7 & 21.2 & 16 & & \\
\hline Vozarci-no N $^{\circ}$ & 16 & 7.5 & 16.5 & 10 & 14 & 12.2 & & & & & 31.5 & 17.7 \\
\hline Vozarci-mean & 16.3 & 7.1 & 16.7 & 10.1 & 15.2 & 12.2 & 15 & 12.7 & 21.2 & 16 & 33.3 & 18.3 \\
\hline
\end{tabular}

